This document is the accepted manuscript version of the following article:

Eckmeier, E., Egli, M., Schmidt, M. W. I., Schlumpf, N., Nötzli, M., Minikus-

Stary, N., \& Hagedorn, F. (2010). Preservation of fire-derived carbon compounds and sorptive stabilisation promote the accumulation of organic matter in black soils of the Southern A1ps. Geoderma, 159(1-2), 147-155.

https://doi .org/10.1016/j.geoderma.2010.07.006

\title{
Preservation of fire-derived carbon compounds and sorptive stabilisation promote the accumulation of organic matter in black soils of the Southern Alps
}

E. Eckmeier ${ }^{\text {a,b* }}$, M. Egli ${ }^{a}$, M.W.I. Schmidt ${ }^{a}$, N. Schlumpf ${ }^{a}$, M. Nötzlic, N. MinikusStary $^{\mathrm{a}}$, F. Hagedorn ${ }^{\mathrm{c}}$

${ }^{a}$ University of Zurich, Department of Geography, Winterthurerstrasse 190, 8057 Zurich, Switzerland.

${ }^{\mathrm{b}}$ University of Bonn, INRES - Soil Science and Soil Ecology, Nussallee 13, 53115 Bonn, Germany.

${ }^{\mathrm{c} S w i s s}$ Federal Institute for Forest, Snow and Landscape Research (WSL), Zürcherstrasse 111, 8903 Birmensdorf, Switzerland.

* Corresponding author. Email address: eileen.eckmeier@uni-bonn.de

\begin{abstract}
Cryptopodzols are black soils that occur under forests dominated by chestnut trees (Castanea sativa) in Southern Switzerland. Their soil organic carbon (SOC) stocks reach an average of $150 \mathrm{t} \mathrm{C} \mathrm{ha}^{-1}$ and are thus among the highest of European forest soils.

We investigated the processes leading to the accumulation and stabilisation of SOC in these soils by analysing three Cryptopodzols and one Cambisol for charred organic matter content (macrocharcoal and BPCA), the amounts of Fe and Al, and the colour and SOC content in bulk soil and density fractions. The results showed that charred organic matter produced by frequent fires in the area for at least 10,000 years is highly abundant in Cryptopodzols: the stocks of macrocharcoal and BPCA-C amount to up to $31 \mathrm{t} \mathrm{ha}^{-1}$ and $17 \mathrm{t} \mathrm{ha}^{-1}$, respectively. These high amounts of charred organic matter are responsible for the dark soil colour and high SOC concentrations that are, however, also closely related to $\mathrm{Fe}_{\mathrm{p}}$ and $\mathrm{Al}_{\mathrm{p}}$ concentrations. We concluded that the ocurrence of charcoal across the whole profiles of Cryptopodzols seems to be the dominating factor, although both the formation of organo-metallic or organo-mineral complexes in the subsoil and the high abundance and stability of charred organic matter are responsible for the high SOC stocks in Cryptopodzols.
\end{abstract}

\section{Keywords}

soil organic matter, charcoal, BPCA, Fe/Al oxides, density separation 


\section{Introduction}

Soils of Southern Switzerland are often characterised by a black colour throughout the profile down to the parent material (Blaser et al., 1997). These soils occur mainly under forests dominated by chestnut trees (Castanea sativa) at elevations below $1000 \mathrm{~m}$ asl. Their mean soil organic carbon (SOC) stocks of $150 \mathrm{t} \mathrm{C} \mathrm{ha}^{-1}$ are the highest in Switzerland (Perruchoud et al., 2000) and among the highest in European forest soils (Liski et al., 2002).

Blaser et al. (1997) classified these soils as Cryptopodzols. They have features of Podzols because pedogenic oxides were eluviated from the topsoil, but the typically bleached eluviation horizon is masked by a dark soil colour. Blaser et al. (1997) explained the high amounts of SOC and the dark colour with the presence of both tannin-rich chestnut litter and aluminium $(\mathrm{Al})$ and iron $(\mathrm{Fe})$ in the parent material. The very low bulk density $\left(<1 \mathrm{~g} \mathrm{~cm}^{-3}\right)$ of Cryptopodzols and the humid climate of the Southern Alps promote the leaching of dissolved organic carbon, including tannins and other polyphenols, from the litter layer through the soil profile, where the organic matter readily forms organo-metallic complexes with $\mathrm{Al}$ and $\mathrm{Fe}$ oxides. These complexes stabilise SOC in the mineral soil matrix, and therefore are responsible for the high SOC contents and the dark soil colour (Blaser and Sposito, 1987; Blaser et al., 1997). The importance of organo-metallic complexes as stabilising agents is pronounced especially when allophanes and imogolites are present in the subsoils of Cryptopodzols (Zanelli et al., 2006).

Stabilisation processes of organic matter in soils are, nonetheless, still not well understood. Theoretical concepts of SOC stabilisation describe different mechanisms of protection: (1) recalcitrance of organic matter due to the primary or secondary molecular structure, (2) spatial inaccessibility, i.e. inclusion of organic matter into aggregates or micropores, which leads to a physical protection of organic matter from microorganisms and enzymes, and (3) sorption processes on minerals and interaction with metal ions that are known to play an important role in SOM preservation (Sollins et al., 1996; Baldock et al., 2004; von Lützow et al., 2006; Wiseman and Püttmann, 2006).

The knowledge about binding mechanisms between SOC and mineral surfaces that have been identified derived mainly from statistical correlations between soil mineralogy and the presence of soil organic matter (Kögel-Knabner et al., 2008). Stable 
SOC in acidic temperate soils seems to be predominantly associated with Fe oxides and short-range order Al silicates, which provide large reactive surface areas (Eusterhues et al., 2005) with hydroxyl groups (Kögel-Knabner et al., 2008). The findings of Mikutta et al. (2006) and Wiseman and Püttmann (2005) suggested that amorphous or poorly crystalline phases are the main binding reagents. The separation of soils into density fractions showed that a large proportion of SOC in subsoils is associated with the heavy fraction due to complexation of SOC with mineral surfaces, and that the proportion increases with depth (Schulten and Leinweber, 2000). The mean residence time of SOC increases with increasing density, which indicates that the mineral-associated heavy fraction comprises stable SOC fractions (e.g., Sollins et al., 2006).

The black colour and the stabilisation of SOC in Cryptopodzols might also be related to the accumulation of charred organic matter. Fires have been a common feature of southern Alpine forests for at least 10,000 years (Tinner et al., 1999). Wildfires during the frequent dry periods and deliberate burning, used to promote the growth of chestnut trees in the region, has produced significant amounts of charred organic matter (Hajdas et al., 2007). Charcoal is considered to be highly resistant to decomposition due to its condensed aromatic structure and can, therefore, persist in soils or sediments over millennia (Bird and Cali, 1998; Skjemstad et al., 2004). The resistance of charcoal to biological or chemical decomposition is determined by the combustion conditions and depends on the elemental composition or chemical recalcitrance of the individual charcoal components (Krull et al., 2006). Recent studies, however, showed that charcoal particles or certain compounds of fire-derived organic matter, seem to be susceptible to surface oxidation and subsequent microbial decomposition (Cheng et al., 2006; Hockaday et al., 2007).

For the black soils in Southern Switzerland, it is hypothesised that a combination of two main mechanisms have led to the development of dark soil colour and high SOC stocks: the accumulation of charred organic matter by frequent fires, and sorptive processes like the formation of organo-metallic associations. We investigated charred organic matter (charcoal and BPCA), as well as $\mathrm{Fe}$ and $\mathrm{Al}$ oxides in three Cryptopodzols of Southern Switzerland and compared the results with a Cambisol.

This study aimed at identifying the importance of the two processes, structural recalcitrance and interaction with minerals, for the stabilisation of SOC in the investigated Cryptopodzols. If structural recalcitrance was the mechanism that led to the 
high SOC stocks in Cryptopodzols, then one would expect to observe a close relationship between SOC and BPCA or macrocharcoal concentrations. The interaction with metals would be expressed by a close relationship between SOC and Fe and $\mathrm{Al}$ compounds.

\section{Materials and methods}

Study sites

We investigated four soil profiles located in the Southern Alps of Switzerland (Ticino; Figure 1). The humid and moderate climate in the area is characterised by a mean annual temperature of $12^{\circ} \mathrm{C}$ (January, $1{ }^{\circ} \mathrm{C}$; July, $22^{\circ} \mathrm{C}$; Eidgenössisches Department des Innern, 1992) and a mean annual precipitation of $1800 \mathrm{~mm}$ (Lugano, $273 \mathrm{~m}$ asl). Forest fires are common during the rather dry winter period. Spring and autumn are generally humid, whereas the summers are sunny but have sporadic thunderstorms. Below 1000 $\mathrm{m}$ asl the deciduous forests are dominated by chestnut trees (Castanea sativa Mill). Other important tree species are Quercus petraea (Matt.) Liebl. and Quercus pubescens Willd., Alnus glutinosa Gaertner, Fraxinus excelsior L., Betula pendula Roth., Fagus silvatica L. and Tilia cordata Mill. At higher elevations (>1000 m asl) stands of Abies alba and Picea abies prevail, partly mixed with Fagus silvatica and Sorbus aucuparia (Brassel and Brändli, 1999).

We studied three Cryptopodzols and a Cambisol at different locations (Table 1). Two sites (Cryptopodzols; P1, Pian d'Arf and P3, Prebonella) are located in the Misox valley near Roveredo (Grisons). The third Cryptopodzol (P2) is situated near Pura (Ticino) in the area of Lago di Lugano. The Cryptopodzols developed on crystalline parent material (Gneiss). The fourth profile (P4), a Cambisol, is located close to the Italian border near Sagno and developed on siliceous Mesozoic sediments that contain some carbonates (Flysch).

\section{Soil sampling and analyses}

Soil samples of 1-2 kg were collected from each horizon. A high amount of material for analyses is required to obtain representative values for soils in Alpine environments. The error range due to soil variability can be kept below $10 \%$ for organic $\mathrm{C}$ and $\mathrm{N}$ by using large bulk sample sizes (see Hitz et al., 2002). Soil bulk density (three replicates; error range $<10 \%$; see Hitz et al., 2002) was determined using soil cores and by 
volume replacement in stony soils. Soil samples were dried at $40^{\circ} \mathrm{C}$, soil aggregates were crushed and material $>2 \mathrm{~mm}$ (soil skeleton) was removed by sieving. Total $\mathrm{C}$ and $\mathrm{N}$ contents of fine-earth material were measured with an elemental analyzer (Elementar Vario EL). The analytical error range is $\pm 2.5 \%$. Measurements were controlled with a well-defined soil standard (S3, Kantonales Labor Zürich). Soil pH was determined in $0.01 \mathrm{M} \mathrm{CaCl}_{2}$ by using a soil:solution ratio of 1:2.5. After a pre-treatment with $\mathrm{H}_{2} \mathrm{O}_{2}$ (3\%), particle size distribution of the soils was determined by sieving the coarser particles $(2000-32 \mu \mathrm{m})$ and measurement of the smaller size-fraction $(<32 \mu \mathrm{m})$ with an X-ray-sedimentometer (SediGraph 5100) according to Stoke's law (Gee and Bauder, 1986).

Macrocharcoals, i.e. carbonised fragments of wood that are visible by the naked eye (diameter $>2 \mathrm{~mm}$ ) were separated from the soils by hand. The material was floated in water, the remnants were rinsed through a sieve and dried at $40^{\circ} \mathrm{C}$. A selection of charcoal particles was radiocarbon dated after the wood species had been identified. The oldest charcoal (11180 \pm 75 BP or 11270-10980 calBC; Pinus sp.) was found in Cryptopodzol Pura (P2) at the transition from B to C horizon. ${ }^{14} \mathrm{C}$ AMS data and charcoal wood species were published in Hajdas et al. (2007).

Black carbon concentrations were determined in fine-earth using the benzene polycarboxylic acid (BPCA) marker method as described by Brodowski et al. (2005b). Results are given in the following as BPCA carbon (BPCA-C). The samples (three replicates) were first treated with trifluoroacetic acid (TFA) to remove polyvalent cations and then digested with $\mathrm{HNO}_{3}$ at $170{ }^{\circ} \mathrm{C}$ for eight hours. After filtration the sum of BPCAs in each sample was analysed after derivatisation on a gas chromatograph equipped with a flame ionisation detector.

The dithionite-, pyrophosphate- and oxalate-extractable fractions were measured for the elements Fe and $\mathrm{Al}$ (McKeague et al., 1971). The extracts were centrifuged for $10 \mathrm{~min}$ at $4000 \mathrm{rpm}$ and then filtered through a $0.45 \mu \mathrm{m}$ filter (S\&S, filtertype 030/20). Element concentrations were measured by atomic absorption spectroscopy (AAS).

The pyrophosphate extraction is often used to characterise the organically-bound Al fraction. There are, however, some limitations regarding this method (Kaiser and Zech, 1996). Kleber et al. (2004) presumed that the alkaline pyrophosphate extractant attacks not only organic fractions but, to a certain degree, also hydroxy-like $\mathrm{Al}$ in the interlayers of clay minerals or gibbsite. The dithionite reagent extracts various forms of 
organic and inorganic $\mathrm{Al}$ and $\mathrm{Fe}$ : organic $\mathrm{Al}$, noncrystalline and crystalline oxyhydroxides (e.g., Al substituted in ferrihydrite and goethite), some Al in hydroxy interlayers and allophanes (Wada, 1977; Shoji and Fujiwara, 1984; Borggaard, 1988; Dahlgren and Ugolini, 1991), organically-bound Fe, noncrystalline and crystalline Feoxyhydroxides and also Fe-bearing silicates, especially nontronite (Borggaard, 1988). The oxalate extraction dissolves organically-bound forms as well as weakly or noncrystallised forms.

The soil lightness was expressed as L* (CIE 1976 Standard Observer). The L* values indicate the extinction of light on a scale from $\mathrm{L}^{*} 0$ (absolute black) to $\mathrm{L}^{*} 100$ (absolute white). The dried, homogenised but not ground soil samples were measured in triplicates using a spectrophotometer (Dr. Lange spectro-color) by observing the diffused reflected light under standardised observation conditions.

The density fractionation procedure was adapted from Christensen (1992) and Glaser et al. (2000). The following fractions were separated: $<1.0 \mathrm{~g} \mathrm{~cm}^{-3}, 1.0-2.0 \mathrm{~g} \mathrm{~cm}^{-}$ ${ }^{3}, 2.0-2.4 \mathrm{~g} \mathrm{~cm}^{-3}$ and $>2.4 \mathrm{~g} \mathrm{~cm}^{-3}$. According to Glaser et al. (2000) and Sollins et al. (2006) the light fraction $<1.0 \mathrm{~g} \mathrm{~cm}^{-3}$ includes plant-derived polysaccharides, lignin, cutin, suberin and charcoal. The fraction $1.0-2.0 \mathrm{~g} \mathrm{~cm}^{-3}$ contains, besides a high amount of organic carbon, also a mineral fraction ("organo-mineral" fraction). In fraction 1.0$2.0 \mathrm{~g} \mathrm{~cm}^{-3}$ and especially in fraction $>2.0 \mathrm{~g} \mathrm{~cm}^{-3}$ aggregates and organo-mineral associations increasingly protect organic material from decay (Christensen, 1992; Egli et al., 2009). In fraction 2.0-2.4 $\mathrm{g} \mathrm{cm}^{-3}$ most soil organic matter should be adsorbed to metals and minerals, the mineral components generally prevail. Density fractions were separated according to Christensen (1992) using a sodium polytungstate density solution: (1) $20 \mathrm{~g}$ of soil was put into suspension in $1000 \mathrm{ml}$ water and after $2 \mathrm{~h}$ the fraction $d \leq 0.998 \mathrm{~g} \mathrm{~cm}^{-3}$, which was floating on the surface, was recovered by filtering; (2) the aggregates in $5 \mathrm{~g}$ soil $\left(d>0.998 \mathrm{~g} \mathrm{~cm}^{-3}\right)$, suspended in $25 \mathrm{ml}$ density solution $(d$ $\left.=2 \mathrm{~g} \mathrm{~cm}^{-3}\right)$, were dispersed using ultrasonic $\left(50 \mathrm{~J} \mathrm{ml}^{-1}\right)$ and the fraction $d \leq 2 \mathrm{~g} \mathrm{~cm}^{-3}$ was separated by filtering after centrifugation of the solution; (3) $25 \mathrm{ml}$ density solution ( $d=$ $2.4 \mathrm{~g} \mathrm{~cm}^{-3}$ ) was added to the material left in the centrifuge beaker and after ultrasonic dispersion $\left(50 \mathrm{~J} \mathrm{ml}^{-1}\right)$ and centrifugation the fraction $d=2-2.4 \mathrm{~g} \mathrm{~cm}^{-3}$ was separated by filtering; (4) the material left in the centrifuge beaker is the fraction $d>2.4 \mathrm{~g} \mathrm{~cm}^{-3}$. The washed and dried samples were analysed for lightness, carbon and nitrogen as described 
before. Only a few samples of the fraction $<1 \mathrm{~g} \mathrm{~cm}^{-3}$ could be analysed for soil colour due to the very small amounts of sample recovered.

\section{Results}

\section{Bulk soil}

All soils contain large amounts of skeleton material (particle size $>2 \mathrm{~mm}$ ), which is typical for soils of mountainous areas (Table 2). They have a sandy to silty-sandy texture, are deeply acidified and have a very low bulk density $\left(<1 \mathrm{~g} \mathrm{~cm}^{-3}\right)$ in the topand subsoil.

Soil organic carbon (SOC) concentrations were high in all soils, with similar values in the upper horizons (Table 3). The Cryptopodzols had particularly high SOC concentrations in the $\mathrm{B}$ horizons with values of up to $66 \mathrm{~g} \mathrm{C} \mathrm{kg}^{-1}$ (P2). The SOC concentrations decreased with depth with the exception of Cryptopodzol P1, where concentrations were relatively low between 15 to $50 \mathrm{~cm}$ depth, but higher in the deeper soil horizons.

The organic $\mathrm{C}$ stocks of the whole soil profiles (without C-horizon) were more than two to three times higher in the Cryptopodzols (241 to $339 \mathrm{t} \mathrm{C} \mathrm{ha}^{-1}$ ) than in the Cambisol $\left(110 \mathrm{t} \mathrm{C} \mathrm{ha}^{-1}\right)$. The high SOC concentration in Cryptopodzol P1 was also reflected by the high SOC stock in the subsoil horizon $\mathrm{A} 1 \mathrm{~b}\left(161 \mathrm{t} \mathrm{C} \mathrm{ha}^{-1}\right)$.

All Cryptopodzol profiles were rich in charcoal fragments throughout the whole soil, in contrast to the Cambisol that contained only very few macrocharcoal particles. The largest stock of charcoal was found in Cryptopodzol P1 with $31 \mathrm{t}$ charcoal ha ${ }^{-1}$ (total profile), where horizon A1b contained a remarkably high amount of charcoal.

Charred organic carbon, determined using the molecular marker BPCA, was present in all profiles. BPCA carbon (BPCA-C) concentrations and stocks were smallest in the Cambisol. In the Cryptopodzols, concentrations reached more than $6.6 \mathrm{~g}$ BPCA-C $\mathrm{kg}^{-1}$ (AE horizon, P2). Similar to the distribution of charcoal, BPCA-C concentrations were, in general, largest in the deeper A or B horizons. The proportion of BPCA-C to SOC was highest in Cryptopodzol P1, where it reached $13 \%$ in the subsoil. The total

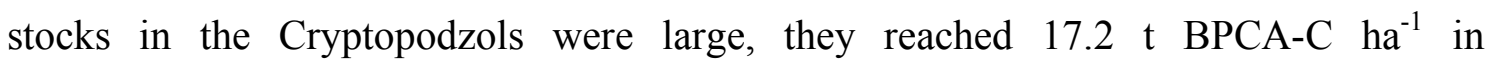
Cryptopodzol P1, with the horizon A1b having the largest stock $\left(6.1 \mathrm{t} \mathrm{ha}^{-1}\right)$.

The soil colour (Table 2) was darkest in Cryptopodzol P2 (min. L* = 26) and lightest in the Cambisol (min. $L^{*}=47$ ). The Cryptopodzols, with the exception of the 
A-horizon of profile P1, were very dark throughout the soil profile, down to the deepest B-horizons.

The extractable $\mathrm{Al}$ and Fe concentrations (dithionite, oxalate and pyrophosphate; Table 4) were in a similar range in all Cryptopodzols, while the amounts were lower in the Cambisol. Noticeable is the increase in $\mathrm{Al}$ and $\mathrm{Fe}$ in the lower A-horizons of Cryptopodzol P1. The pyrophosphate-extractable Fe and Al contents in the topsoil of Cryptopodzol P2 exceeded the oxalate extractable fraction. $\mathrm{Fe}_{\mathrm{p}}$ and $\mathrm{Al}_{\mathrm{p}}$ contents often even equaled the dithionite-extractable contents in the topsoil.

\section{Density fractions}

Density fractionation (Figure 2) revealed that the carbon in the topsoil horizons of the Cryptopodzols was mainly present in the lighter fractions $\left(<2.0 \mathrm{~g} \mathrm{~cm}^{-3}\right)$ with a maximum of $94 \%$ in the A horizon of P2. The proportion of SOC in the lightest fraction $\left(<1.0 \mathrm{~g} \mathrm{~cm}^{-3}\right)$ varied among the profiles. While the contribution of SOC in this fraction was very small in Cryptopodzol P1, about half of SOC was present in the lightest fraction in the A horizon of $\mathrm{P} 2$. In contrast, the density fractions in the Cambisol showed an irregular distribution with depth, with surprisingly high proportions of SOC in the fraction $<1.0 \mathrm{~g} \mathrm{~cm}^{-3}$ even in the $\mathrm{C}$ horizon. More than $40 \%$ of total SOC was still present in the fractions $<2.0 \mathrm{~g} \mathrm{~cm}^{-3}$ of the humic B-horizons of the Cryptopodzols, although the proportion of mineral-associated carbon (fractions $>2.0 \mathrm{~g} \mathrm{~cm}^{-3}$ ) increased with depth. The $\mathrm{C} / \mathrm{N}$ ratios (Table 5) do not show clear trends within and between the profiles, they were slightly higher in the fractions $<2.0 \mathrm{~g} \mathrm{~cm}^{-3}$ than in the heavy fraction. The average lightness values increased from $L^{*}=27$ for all samples of the fraction $<2.0 \mathrm{~g} \mathrm{~cm}^{-3}$, which is very dark, to $\mathrm{L}^{*}=67$ in the heavy fractions.

\section{Discussion}

The SOC stocks of the investigated soils reached values of up to $340 \mathrm{t} \mathrm{C} \mathrm{hat}{ }^{-1}$, which is typical for forest soils of Southern Switzerland (Perruchoud et al., 2000), but much higher than the average soil C stocks of $120 \mathrm{t} \mathrm{C} \mathrm{ha}^{-1}$ in Swiss forest soils (Bolliger et al., 2008). They even reached values of Russian Chernozems under grassland which have particularly high carbon stocks (280-340 t C ha ${ }^{-1}$; Torn et al., 2002). Models of SOC stocks using litter inputs from published data, decomposition rates and climatic data had failed to predict the extraordinary high SOC stocks in Southern Switzerland 
(Perruchoud et al., 1999), suggesting that SOC accumulation is not caused by high input of litter but by stabilisation mechanisms in the soil. SOM stabilisation in soils is still controversially discussed. As an example, Krull et al. (2006) considered molecular recalcitrance as the main trigger of long-term SOM stabilisation. Others concluded that, except for charred organic matter, there is hardly any analytical evidence for intrinsic molecular recalcitrance being a major stabilisation factor in soils, and that aliphatic compounds, polysaccharides and proteinaceous moieties were found in relatively old SOM fractions (Gleixner et al., 2002; Knicker, 2004; Marschner et al., 2008).

\section{Is SOM stabilised by organo-metallic complexes?}

Organo-mineral interactions are generally thought to be the main mechanism for SOM stabilisation in Podzols and other acidic soils (Lundström et al., 2000a, 2000b; Nierop et al., 2002; Kleber et al., 2005). Blaser et al. (1997) concluded that mainly organometallic complexes are responsible for the stabilisation of SOM and the high SOC stocks in Cryptopodzols.

Cryptopodzolic soils usually occur under chestnut (Castanea sativa) stands. Decomposing chestnut wood and leaves release tannins and other polyphenols (Luster et al., 1996). Polyphenols are incorporated into the soil as compounds of dissolved organic matter (DOM), where they bind with $\mathrm{Al}, \mathrm{Fe}$ and other trace metals that derive from the parent material (Blaser and Sposito, 1987; Brunner and Blaser, 1989). The Cryptopodzols of Southern Switzerland contain more sesquioxides than Cambisols of the Swiss Plateau (Zimmermann et al., 2006). Zanelli et al. (2006) found that Cryptopodzols display early stages of podzolisation, and that they contain imogolites and allophanes in the subsoil that are capable of forming strong organo-mineral complexes. Organo-metallic complexes are typical for Andosols, which have characteristics similar to the Cryptopodzols. They are very dark, rich in charred organic matter and poorly crystalline $\mathrm{Al}$ and $\mathrm{Fe}$-oxides $\left(\mathrm{Al}_{\mathrm{o}}, \mathrm{Fe}_{\mathrm{o}}\right)$. Low alkyl $\mathrm{C}$ values and the presence of allophanes suggested that aluminium-organic complexes protect SOM from microbial breakdown (Baldock et al., 1992; Golchin et al., 1997a, 1997b).

The contents of $\mathrm{Fe}$ and $\mathrm{Al}$ oxides of all three Cryptopodzols increased from the A to Bhs horizons (Table 4) which is indicative for the podzolization in these profiles. As shown in Figure 3, the SOC concentrations in all soils were more closely related to the pyrophosphate-extractable and therefore organically bound iron $\left(\mathrm{R}^{2}=0.645, \mathrm{p}<0.001\right)$ 
and aluminium $\left(\mathrm{R}^{2}=0.502, \mathrm{p}<0.001\right)$ than to BPCA-C concentrations $\left(\mathrm{R}^{2}=0.346, \mathrm{p}<\right.$ $0.01)$. SOC and oxalate-extractable iron $\left(\mathrm{R}^{2}=0.275, \mathrm{p}<0.05\right)$ correlated whereas the correlation with aluminium $\left(\mathrm{R}^{2}=0.089, \mathrm{p}>0.05\right)$ was not significant. Organicallybound iron seems to influence the soil colour $\left(\mathrm{L}^{*}\right)$ less $\left(\mathrm{R}^{2}=0.384, \mathrm{p}<0.01\right)$ than the SOC concentration $\left(\mathrm{R}^{2}=0.662, \mathrm{p}<0.001\right)$, as shown in Figures 3 and 4 . The correlation of $\mathrm{L}^{*}$ with SOC could be described with a polynomal regression - indicating that a small increase in SOC rapidly darkens the soil until a certain level is reached.The correlation analysis supports the concept of SOM stabilisation by sesquioxides and metal-organic complexes (cf. correlation with $\mathrm{Fe}_{\mathrm{p}}$ and $\mathrm{Al}_{\mathrm{p}}$, see also Zanelli et al., 2007). For individual profiles, the proportions of SOM in the medium and heavy density fractions increased with soil depth (Figure 2), which indicated an increasing contribution of organo-mineral complexes and of SOM coatings on mineral matter (Glaser et al., 2000). With an average of $45 \%$ in the whole profile, a higher proportion of SOC was found in the light fractions of the Cryptopodzols than of the Cambisols (33 $\%$ ). This strongly suggests that not only organo-mineral associations but also the resistance of particulate organic matter (charcoal) against decomposition contributed to the extraordinary high SOM stocks in the Cryptopodzols, especially when considering that charred organic matter could be also present in the medium and heavy density fractions (Glaser et al., 2000).

The stabilisation mechanisms, however, could not be easily assigned to organomineral interactions or chemical recalcitrance because one Cryptopodzol (P1) exhibited significant erosion and accumulation features (see Table 2). According to mineralogical investigations (X-ray diffraction, FTIR analyses; Nötzli, 2005), it is highly probable that less weathered material was deposited on top of a former soil at Cryptopodzol P1. The statistically based process analysis may have been partially influenced by this effect.

\section{Charcoal as potentially recalcitrant carbon compound?}

Some organic compounds like charcoal are considered to be of secondary recalcitrance, i.e. the chemistry of primary molecules has been altered by polycondensation or polymerisation (von Lützow et al., 2006). In soil carbon models, the charcoal fraction is therefore considered as an inert pool (Skjemstad et al., 2004), although it is known that charcoal could become more functionalised and degrades over time, which makes it susceptible to decomposition (Bird et al., 2002; Cheng et al., 2006; Cohen-Ofri et al., 
2006; Hockaday et al., 2006). The radiocarbon ages of charcoal particles found in our soils that reach up to 13,000 years BP (Hajdas et al., 2007), however, indicated that macrocharcoal was stable over millennia.

Charcoal and BPCA-C were found in all soils, with highest amounts in the Cryptopodzols. Cryptopodzol P1 contained the highest stocks of charcoal and BPCA-C. Taking into account that ca. $70 \%$ of charcoal is carbon (Eckmeier et al., 2007b), the calculated macrocharcoal $\mathrm{C}$ stock in this profile would be $22 \mathrm{t} \mathrm{C} \mathrm{ha}^{-1}$. Mean BPCA and charcoal $\mathrm{C}$ stocks together were $39 \mathrm{t} \mathrm{C} \mathrm{ha}^{-1}$, which accounts for $12 \%$ of total SOC stocks.

Although the distribution of charcoal and BPCA in the soils was similar, BPCA-C stocks correlated better with SOC stocks $\left(\mathrm{R}^{2}=0.429, \mathrm{p}<0.01\right)$ than with charcoal mass stocks $\left(\mathrm{R}^{2}=0.211, \mathrm{p}<0.05\right)$, probably because we determined macrocharcoal in the fraction $>2 \mathrm{~mm}$ and because it can be composed of variable amounts of carbon, depending on fire properties and wood type. Charcoal stocks, however, correlated well to the pattern of SOC stocks in all profiles $\left(\mathrm{R}^{2}=0.541, \mathrm{p}<0.001\right)$.

Data on BPCA-C stocks in other soils are rare. With stocks of 6 to $17 \mathrm{t}$ BPCA-C $\mathrm{ha}^{-1}$ the investigated Cryptopodzols are close to values of carbon-rich Chernozems from fire-prone ecosystems (Rodionov et al., 2010, note that BPCA-C was multiplied by a conversion factor of 2.27). Hammes et al. (2008) estimated BPCA-C stocks of 20 and $19 \mathrm{t} \mathrm{C} \mathrm{ha}^{-1}$ for two Russian Chernozem profiles, a German chernozem-like soil contained $10 \mathrm{t}$ BPCA-C ha- ${ }^{-1}$ (Kleber et al., 2003).

Across all soils, BPCA-C concentrations did not explain the amount of SOC very well $\left(\mathrm{R}^{2}=0.346, \mathrm{p}<0.01\right)$. The contribution of BPCA-C to the total SOC in our soils reached a maximum of $12.5 \%$ BPCA-C at 110-140 cm depth of profile P1. BPCA-data for other fire-affected soils is in most cases only available for topsoils. This data shows comparable proportions, e.g. in topsoils of German Chernozems and Phaeozems (54-65 g BPCA-C kg-1 SOC; Brodowski et al., 2005b). Rodionov et al. (2006) measured BPCAs in whole soil profiles in the Russian steppe and also found a maximum in the subsoil, between 30 and $50 \mathrm{~cm}$ depth, which was related to leaching and particulate transport as well as to decreasing BPCA ratios by inputs of fresh organic matter from plant roots. Dai et al. (2005) measured BPCAs in a fire-prone mixed-grass savannah in depths of up to $20 \mathrm{~cm}$ and also observed an increase with depth (5-9 \% BPCA-C at 0-10 $\mathrm{cm}, 7-13 \%$ BPCA-C at 10-20 cm). 
As shown in Figures 3 and 4, the soil colour $\left(\mathrm{L}^{*}\right)$ of all samples correlated significantly with the BPCA-C concentration $\left(\mathrm{R}^{2}=0.625, \mathrm{p}<0.001\right)$ and the SOC concentration $\left(\mathrm{R}^{2}=0.662, \mathrm{p}<0.001\right)$. The same trend is visible in the density fractions, where the light fractions $\left(<2 \mathrm{~g} \mathrm{~cm}^{-3}\right)$ were darker than the heavier fractions $\left(>2 \mathrm{~g} \mathrm{~cm}^{-3}\right)$, which could be a result of higher SOC concentrations $\left(\mathrm{R}^{2}=0.619, \mathrm{p}<0.001\right)$. These results are consistent with findings from Spielvogel et al. (2004) and Eckmeier et al. (2007a) who showed that soil colour is related to aromatic C concentrations. It is known from a variety of studies that the light fraction usually contains particulate charcoal (Skjemstad et al., 1996; Golchin et al., 1997a; Brodowski et al., 2005a; Sollins et al., 2006). Glaser et al. (2000) measured BPCA-C also in the medium and heavy fractions of Terra Preta soils, but the highest concentrations were found in the light fractions. They concluded that inert particulate black carbon is responsible for the high charred organic matter concentrations in Terra Preta soils.

The large stocks of charcoal fragments and the high radiocarbon ages of charcoal particles indicate that both the high fire frequency in Southern Switzerland (Tinner et al., 1999; Hajdas et al., 2007) and/or the slow degradation or even chemical recalcitrance of charcoal contributed substantially to the long-term $\mathrm{C}$ storage in these soils.

Is charred organic matter stabilised by organo-mineral complexes?

We found that not only SOC concentrations in general but also the BPCA-C concentrations correlated closely with $\mathrm{Fe}_{\mathrm{p}}\left(\mathrm{R}^{2}=0.573, \mathrm{p}<0.001\right)$ and $\mathrm{Al}_{\mathrm{p}}\left(\mathrm{R}^{2}=0.737\right.$, $\mathrm{p}<0.001)$. Some SOC seemed to be stabilised by Fe-oxyhydroxides due to the correlation of SOC with $\mathrm{Fe}_{\mathrm{o}}\left(\mathrm{R}^{2}=0.524, \mathrm{p}>0.05\right)$. There is no significant correlation of BPCA-C with $\mathrm{Fe}_{\mathrm{o}}$ and $\mathrm{Al}_{\mathrm{o}}$. This suggests the presence of solid metal-organic complexes in which BPCA-C is specifically involved.

Andosols in Japan have characteristics similar to the Cryptopodzols. They are very dark, have a high $\mathrm{C}$ content and are found in frequently burned grassland areas. Andosols are rich in charred organic matter and poorly crystalline $\mathrm{Al}$ and $\mathrm{Fe}$ oxides. Baldock et al. (1992) and Golchin et al. (1997a, 1997b) showed, among others, that aluminium-organic complexes in Andosols, favoured by the presence of allophanes, protect SOM from microbial breakdown. 
Mineral compounds could be trapped physically within the fine pores of charcoal particles, or they could bind to the oxidized functional groups (carboxylic and phenolic functionalities) on the char surfaces (Glaser et al., 2002; Lehmann et al., 2005), especially of older charcoal particles (Cohen-Ofri et al., 2006). Brodowski et al. (2005a) investigated black carbon particles in different soil density fractions with SEM/EDX and found that despite being subject to ultrasonic treatment the particles stayed attached to minerals. They suggested that these interactions were facilitated by the relatively large surface areas of black carbon particles together with the occurrence of reactive deprotonated functional groups, and that the formation of organo-mineral complexes could lead to the formation of aggregates, which physically protect the charcoal from further decay. A similar mechanism must also be assumed for the investigated soils where organo-mineral complexes could contain a substantial amount of BPCA-C and protect it from biodegradation. In addition, we hypothesise that a significant part of the charred organic material, e.g. the very old charcoal, must degrade very slowly.

\section{Conclusions}

Our study on SOM stabilisation in C-rich soils in Southern Switzerland showed that: (i) charcoal, which has been present in the soils for 13,000 years, and BPCA-C can be detected in much higher concentrations and stocks in the Cryptopodzols than in the Cambisol; (ii) charred organic matter, measured as BPCA, intensifies the dark soil colour; (iii) the amount of SOC and BPCA-C correlated well with the concentrations of pyrophosphate-extractable, organically bound Al and Fe fractions in the soils; and (iv) SOC was mainly present in the light fraction of topsoils, but also in the medium and heavy fractions in the subsoil horizons. Our results suggest that organo-mineral, or organo-metallic complexation and the recalcitrance of charcoal particles are responsible for stabilising SOM. The presence of free particulate charcoal (not bound to the mineral phase) and its significant correlation to SOC is an evidence that not only sorption to mineral surfaces but also molecular recalcitrance is an important factor. BPCA-C, however, strongly interacts with metals that are organically-bound, and contributes through this mechanism to the stabilisation of SOM. However, the details of chemical interactions and the nature of the formed complexes still remain unclear. We conclude that fire-derived $\mathrm{C}$ contributes significantly to the black colour and to the high $\mathrm{C}$ stocks 
in southern Switzerland. In addition, statistical evidence suggests that sorption processes stabilise plant and, also very likely, fire-derived SOC, mainly in the subsoil.

\section{Acknowledgements}

We would like to express our appreciation to Peter Blaser for initiating the study, to Paolo Cherubini and Irka Hajdas for their support and helpful discussions, and to Bruno Kägi and Michael Hilf for their assistance in the laboratory. We are, furthermore, indebted to two unknown reviewers for their helpful comments on an earlier version of the manuscript. 


\section{References}

Baldock, J.A., Masiello, C.A., Gelinas, Y., Hedges, J.I., 2004. Cycling and composition of organic matter in terrestrial and marine ecosystems. Marine Chemistry 92, 39-64.

Baldock, J.A., Oades, J.M., Waters, A.G., Peng, X., Vassallo, A.M., Wilson, M.A., 1992. Aspects of the chemical structure of soil organic materials as revealed by solid-state ${ }^{13} \mathrm{C}$ NMR spectroscopy. Biogeochemistry 16, 1-42.

Bird, M.I., Cali, J.A., 1998. A million-year record of fire in sub-Saharan Africa. Nature 394, 767-769.

Bird, M.I., Turney, C.S.M., Fifield, L.K., Jones, R., Ayliffe, L.K., Palmer, A., Cresswell, R., Robertson, S., 2002. Radiocarbon analysis of the early archaeological site of Nauwalabila I, Arnhem Land, Australia: implications for sample suitability and stratigraphic integrity. Quaternary Science Reviews 21, 1061-1075.

Blaser, P., Kernebeek, P., Tebbens, L., Van Breemen, N., Luster, J., 1997. Cryptopodzolic Soils in Switzerland. European Journal of Soil Science 48, 411-423.

Blaser, P., Sposito, G., 1987. Spectrofluorometric Investigation Of Trace-Metal Complexation By An Aqueous Chestnut Leaf Litter Extract. Soil Science Society of America Journal 51, 612-619.

Bolliger, J., Hagedorn, F., Leifeld, J., Böhl, J., Zimmermann, S., Soliva, R., Kienast, F., 2008. Effects of land-use change on carbon stocks in Switzerland. Ecosystems 11, 895-907.

Borggaard, O.K., 1988. Phase indication by selective dissolution techniques. In: J. W.

Stucki, B.A. Goodman and U. Schwertmann (Editors), Iron in Soils and Clay

Minerals. D. Reidel Publishing Company, Dordrecht, pp. 83-89.

Brassel, P., Brändli, U.B., 1999. Schweizerisches Landesforstinventar. Ergebnisse der Zweitaufnahme 1993-1995. Eidgenössische Forschungsanstalt für Wald, Schnee und Landschaft, Bundesamt für Umwelt, Wald und Landschaft, Birmensdorf, Bern.

Brodowski, S., Amelung, W., Haumaier, L., Abetz, C., Zech, W., 2005a. Morphological and chemical properties of black carbon in physical soil 
fractions as revealed by scanning electron microscopy and energy-dispersive X-ray spectroscopy. Geoderma 128, 116-129.

Brodowski, S., Rodionov, A., Haumaier, L., Glaser, B., Amelung, W., 2005b. Revised black carbon assessment using benzene polycarboxylic acids. Organic Geochemistry 36, 1299-1310.

Brunner, W., Blaser, P., 1989. Mineralization of soil organic matter and added carbon substrates in two acidic soils with high non-exchangeable aluminum. Zeitschrift für Pflanzenernährung und Bodenkunde 152, 367-372.

Cheng, C.-H., Lehmann, J., Thies, J.E., Burton, S.D., Engelhard, M.H., 2006. Oxidation of black carbon by biotic and abiotic processes. Organic Geochemistry 37, 1477-1488.

Christensen, B.T., 1992. Physical Fractionation of Soil and Organic Matter in Primary Particle Size and Density Separates. Advances in Soil Science, 20. Springer, New York.

Cohen-Ofri, I., Weiner, L., Boaretto, E., Mintz, G., Weiner, S., 2006. Modern and fossil charcoal: aspects of structure and diagenesis. Journal of Archaeological Science 33, 428-439.

Dahlgren, R.A. and Ugolini, F.C., 1991. Distribution and characterization of shortrange-order minerals in Spodosols from the Washington Cascades. Geoderma, 48, 391-413.

Dai, X., Boutton, T.W., Glaser, B., Ansley, R.J., Zech, W., 2005. Black carbon in a temperate mixed-grass savanna. Soil Biology \& Biochemistry 37, 1879-1881.

Eckmeier, E., Gerlach, R., Skjemstad, J.O., Ehrmann, O., Schmidt, M.W.I., 2007a. Minor changes in soil organic carbon and charcoal concentrations detected in a temperate deciduous forest a year after an experimental slash-and-burn. Biogeosciences 4, 377-383.

Eckmeier, E., Rösch, M., Ehrmann, O., Schmidt, M.W.I., Schier, W., Gerlach, R., 2007b. Conversion of biomass to charcoal and the carbon mass balance from a slash-and-burn experiment in a temperate deciduous forest. Holocene 17, 539542.

Egli, M., Sartori, G., Mirabella, A., Favilli, F. 2009. Effect of north and south exposure on organic matter in high Alpine soils. Geoderma 149, 124-136.

Eidgenössisches Department des Innern (EDI), 1992. Hydrologischer Atlas der Schweiz. Landeshydrologie und -geologie, Bern. 
Eusterhues, K., Rumpel, C., Kögel-Knabner, I., 2005. Stabilization of soil organic matter isolated via oxidative degradation. Organic Geochemistry 36, 1567.

Gee, G.W., Bauder, J.W., 1986. Particle size analysis. In: Klute, E. (ed.), Methods of Soil Analysis. Part 1. Physical and Mineralogical Methods. 2nd ed. Soil Science Society of America Inc. and American Society of Agronomy Inc., Madison, Wisconsin, pp. 383-411.

Glaser, B., Balashov, E., Haumaier, L., Guggenberger, G., Zech, W., 2000. Black carbon in density fractions of anthropogenic soils of the Brazilian Amazon region. Organic Geochemistry 31, 669-678.

Glaser, B., Lehmann, J., Zech, W., 2002. Ameliorating physical and chemical properties of highly weathered soils in the tropics with charcoal - a review. Biology and Fertility of Soils 35, 219-230.

Gleixner, G., Poirier, N., Bol, R., Balesdent, J., 2002. Molecular dynamics of organic matter in a cultivated soil. Organic Geochemistry 33, 357-366.

Golchin, A., Baldock, J.A., Clarke, P., Higashi, T., Oades, J.M., 1997a. The effects of vegetation and burning on the chemical composition of soil organic matter in a volcanic ash soil as shown by ${ }^{13} \mathrm{C}$ NMR spectroscopy. II. Density fractions. Geoderma 76, 175-192.

Golchin, A., Clarke, P., Baldock, J.A., Higashi, T., Skjemstad, J.O., Oades, J.M., 1997b. The effects of vegetation and burning on the chemical composition of soil organic matter in a volcanic ash soil as shown by ${ }^{13} \mathrm{C}$ NMR spectroscopy. I. Whole soil and humic acid fraction. Geoderma 76, 155-174.

Hajdas, I., Schlumpf, N., Minikus-Stary, N., Hagedorn, F., Eckmeier, E., Schoch, W., Burga, C., Bonani, G., Schmidt, M.W.I., Cherubini, P., 2007. Radiocarbon ages of soil charcoals from the southern Alps, Ticino Switzerland. Nuclear Instruments and Methods in Physics Research B 259, 398-402.

Hammes, K., Torn, M.S., Lapenas, A.G., Schmidt, M.W.I., 2008. Centennial black carbon turnover observed in a Russian steppe soil. Biogeosciences 5, 13391350 .

Hitz, C., Egli, M., Fitze, P., 2002. Determination of the sampling volume for representative analysis of alpine soils. Journal for Plant Nutrition and Soil Science 165, 326-331.

Hockaday, W.C., Grannas, A.M., Kim, S., Hatcher, P.G., 2006. Direct molecular evidence for the degradation and mobility of black carbon in soils from 
ultrahigh-resolution mass spectral analysis of dissolved organic matter from a fire-impacted forest soil. Organic Geochemistry 37, 501-510.

Hockaday, W.C., Grannas, A.M., Kim, S., Hatcher, P.G., 2007. The transformation and mobility of charcoal in a fire-impacted watershed. Geochimica et Cosmochimica Acta 71, 3432-3445.

IUSS Working Group WRB. World Reference Base for Soil Resources 2006, 2nd edition, World Soil Resources Reports No. 103, FAO (Food and Agriculture Organisation of the United Nations), Rome, 2006.

Kaiser, K., Zech, W., 1996. Defects in estimation of aluminium in humus complexes of podzolic soils by pyrophosphate extraction. Soil Science 161, 452-458.

Kleber, M., Mikutta C., Jahn, R., 2004. Andosols in Germany - pedogenesis and properties. Catena 56, 67-83.

Kleber, M., Mikutta, R., Torn, M.S., Jahn, R., 2005. Poorly crystalline mineral phases protect organic matter in acid subsoil horizons. European Journal of Soil Science 56, 717-725.

Kleber, M., Rössner, J., Chenu, C., Glaser, B., Knicker, H., Jahn, R., 2003. Prehistoric alteration of soil properties in a Central German chernozemic soil: In search of pedologic indicators for prehistoric activity. Soil Science 168, 292-306.

Knicker, H., 2004. Stabilization of N-compounds in soil and organic-matter-rich sediments - what is the difference? Marine Chemistry 92, 167.

Krull, E.S., Swanston, C.W., Skjemstad, J.O., McGowan, J.A., 2006. Importance of charcoal in determining the age and chemistry of organic carbon in surface soils. Journal of Geophysical Research-Biogeosciences 111, G04001, doi: 10.1029/2006JG000194.

Kögel-Knabner, I., Guggenberger, G., Kleber, M., Kandeler, E., Kalbitz, K., Scheu, S., Eusterhues, K., Leinweber, P., 2008. Organo-mineral associations in temperate soils: Integrating biology, mineralogy, and organic matter chemistry. Journal of Plant Nutrition and Soil Science 171, 61-82.

Lehmann, J., Liang, B.Q., Solomon, D., Lerotic, M., Luizão, F., Kinyangi, J., Schäfer, T., Wirick, S., Jacobsen, C., 2005. Near-edge X-ray absorption fine structure (NEXAFS) spectroscopy for mapping nano-scale distribution of organic carbon forms in soil: Application to black carbon particles. Global Biogeochemical Cycles 19, GB1013, doi:10.1029/2004GB002435. 
Liski, J., Perruchoud, D., Karjalainen, T., 2002. Increasing carbon stocks in the forest soils of western Europe. Forest Ecology and Management 160, 159-175.

Lundström, U.S., van Breemen, N., Bain, D., 2000a. The podzolization process. A review. Geoderma 94, 91-107.

Lundström, U.S., van Breemen, N., Bain, D.C., van Hees, P.A.W., Giesler, R., Gustafsson, J.P., Ilvesniemi, H., Karltun, E., Melkerud, P.A., Olsson, M., Riise, G., Wahlberg, O., Bergelin, A., Bishop, K., Finlay, R., Jongmans, A.G., Magnusson, T., Mannerkoski, H., Nordgren, A., Nyberg, L., Starr, M., Tau Strand, L., 2000b. Advances in understanding the podzolization process resulting from a multidisciplinary study of three coniferous forest soils in the Nordic Countries. Geoderma 94, 335-353.

Luster, J., Lloyd, T., Sposito, G., Fry, I.V., 1996. Multi-Wavelength Molecular Fluorescence Spectrometry for Quantitative Characterization of Copper (II) and Aluminium (III) Complexation by Dissolved Organic Matter. Environmental Science and Technology 30, 1565-1574.

Marschner, B., Brodowski, S., Dreves, A., Gleixner, G., Gude, A., Grootes, P.M., Hamer, U., Heim, A., Jandl, G., Ji, R., Kaiser, K., Kalbitz, K., Kramer, C., Leinweber, P., Rethemeyer, J., Schaeffer, A., Schmidt, M.W.I., Schwark, L., Wiesenberg, G.L.B., 2008. How relevant is recalcitrance for the stabilization of organic matter in soils? Journal of Plant Nutrition and Soil Science 171, 91110.

McKeague, J.A., Brydon, J.E., Miles, N.M., 1971. Differentiation of forms of extractable iron and aluminium in soils. Soil Science Society of America Proceedings 35, 33-38.

Mikutta, R., Kleber, M., Torn, M.S., Jahn, R., 2006. Stabilization of soil organic matter: Association with minerals or chemical recalcitrance? Biogeochemistry $77,25-56$.

Nierop, K.G.J., Jansen, B., Verstraten, J.A., 2002. Dissolved organic matter, aluminium and iron interactions: precipitation induced by metal/carbon ratio, pH and competition. Science of the Total Environment 300, 201-211.

Nötzli, M. 2005. Schwarze Böden in der Südschweiz. Eine bodenmineralogische/chemische Prozess-Studie. Diploma thesis, Department of Geography, University of Zürich. 
Perruchoud, D., Kienast, F., Kaufmann, E., Braker, O.U., 1999. 20th century carbon budget of forest soils in the Alps. Ecosystems 2, 320-337.

Perruchoud, D., Walthert, L., Zimmermann, S., Lüscher, P., 2000. Contemporary carbon stocks of mineral forest soils in the Swiss Alps. Biogeochemistry 50, 111-136.

Rodionov, A., Amelung, W., Haumaier, L., Urusevskaja, I., Zech, W., 2006. Black carbon in the zonal steppe soils of Russia. Journal of Plant Nutrition and Soil Science 169, 363-369.

Rodionov, A., Amelung, W., Peinemann, N., Haumaier, L., Zhang, X., Kleber, M., Glaser, B., Urusevskaja, I., Zech, W., 2010. Black carbon in grassland ecosystems of the world. Global Biogeochemical Cycles, doi:10.1029/2009GB003669, in press.

Schulten, H.R., Leinweber, P., 2000. New insights into organic-mineral particles: composition, properties and models of molecular structure. Biology and Fertility of Soils 30, 399-432.

Shoji, S. and Fujiwara, Y., 1984. Active aluminium and iron in the humus horizons of andosols from northeastern Japan: their forms, properties, and significance in clay weathering. Soil Science, 137, 216-226.

Skjemstad, J.O., Clarke, P., Taylor, J.A., Oades, J.M., McClure, S.G., 1996. The Chemistry and Nature of Protected Carbon in Soil. Australian Journal of Soil Research 34, 251-271.

Skjemstad, J.O., Spouncer, L.R., Cowie, B., Swift, R.S., 2004. Calibration of the Rothamsted organic carbon turnover model (RothC ver. 26.3), using measurable soil organic carbon pools. Australian Journal of Soil Research 42, $79-88$.

Sollins, P., Homann, P., Caldwell, B.A., 1996. Stabilization and destabilization of soil organic matter: Mechanisms and controls. Geoderma 74, 65-105.

Sollins, P., Swanston, C., Kleber, M., Filley, T., Kramer, M., Crow, S., Caldwell, B.A., Lajtha, K., Bowden, R., 2006. Organic C and N stabilization in a forest soil: Evidence from sequential density fractionation. Soil Biology and Biochemistry 38, 3313-3324.

Spielvogel, S., Knicker, H., Kögel-Knabner, I., 2004. Soil organic matter composition and soil lightness. Journal of Plant Nutrition and Soil Science 167, 545-555. 
Tinner, W., Hubschmid, P., Wehrli, M., Ammann, B., Conedera, M., 1999. Long-term forest fire ecology and dynamics in southern Switzerland. Journal of Ecology 87, 273-289.

Torn, M.S., Lapenis, A.G., Timofeev, A., Fischer, M.L., Babikov, B.V., Harden, J.W., 2002. Organic carbon and carbon isotopes in modern and 100-year-oldsoil archieves of the Russian steppe. Global Change Biology 8, 941-953.

Torn, M.S., Trumbore, S., Chadwick, O.A., Vitousek, P.M., Hendricks, D.M., 1997. Mineral control of soil organic carbon storage and turnover. Nature 389, 170173.

von Lützow, M., Kögel-Knabner, I., Ekschmitt, K., Matzner, E., Guggenberger, G., Marschner, B., Flessa, H., 2006. Stabilization of organic matter in temperate soils: mechanisms and their relevance under different soil conditions - a review. European Journal of Soil Science 57, 426-445.

Wada, K., 1977. Allophane and imogolite. In: J.B. Dixon and S.B. Weed (Editors), Minerals in soil environment. Soil Science Society of America, Madison, Wis., USA, pp. 603-638.

Wiseman, C.L.S., Püttmann, W., 2005. Soil organic carbon and its sorptive preservation in central Germany. European Journal of Soil Science 56, 65-76.

Wiseman, C.L.S., Püttmann, W., 2006. Interactions between mineral phases in the preservation of soil organic matter. Geoderma 134, 109-118.

Zanelli, R., Egli, M., Mirabella, A., Abdelmoula, M., Plötze, M., Nötzli, M., 2006. 'Black' soils in the southern Alps: Clay mineral formation and transformation, X-ray amorphous Al phases and Fe forms. Clays and Clay Minerals 54, 703720.

Zanelli, R., Egli, M., Mirabella, A., Giaccai, A., Abdelmoula, M. 2007. Vegetation effects on pedogenetic forms of $\mathrm{Fe}, \mathrm{Al}$ and $\mathrm{Si}$ and on clay minerals in soils in southern Switzerland and northern Italy. Geoderma 141, 119-129.

Zimmermann, S., Luster, J., Blaser, P., Walthert, L., Lüscher 2006. Waldböden der Schweiz. Band 3. Regionen Mittelland und Voralpen. Eigenössische Forschungsanstalt WSL, Birmensdorf, Hep Verlag, Bern 848p. 
Table 1 Characteristics of investigated sites.

\begin{tabular}{|c|c|c|c|c|c|c|}
\hline Site & $\begin{array}{l}\text { Altitude } \\
\mathrm{m} \text { asl }\end{array}$ & Exposure & $\begin{array}{l}\text { Slope } \\
\%\end{array}$ & $\begin{array}{l}\text { Dominating } \\
\text { vegetation }\end{array}$ & Soil type & $\begin{array}{l}\text { Geological } \\
\text { substrate }\end{array}$ \\
\hline $\begin{array}{l}\text { Pian d'Arf } \\
\text { P1 }\end{array}$ & 515 & $\mathrm{~N}$ & 35 & $\begin{array}{l}\text { Castanea sativa, } \\
\text { Fagus silvatica, } \\
\text { Picea abies }\end{array}$ & $\begin{array}{l}\text { Humic } \\
\text { Umbrisol }^{2)} \\
\text { Cryptopodzol }^{1)}\end{array}$ & $\begin{array}{l}\text { Granite, } \\
\text { orthogneiss }\end{array}$ \\
\hline $\begin{array}{l}\text { Pura } \\
\text { P2 }\end{array}$ & 650 & SW & 22 & $\begin{array}{l}\text { Castanea sativa, } \\
\text { Fagus silvatica, } \\
\text { Quercus sp. }\end{array}$ & $\begin{array}{l}\text { Humic } \\
\text { Umbrisol }^{2)} \\
\text { Cryptopodzol }^{1)}\end{array}$ & $\begin{array}{l}\text { Granite, } \\
\text { orthogneiss }\end{array}$ \\
\hline $\begin{array}{l}\text { Prebonella } \\
\text { P3 }\end{array}$ & 950 & $E$ & 56 & $\begin{array}{l}\text { Castanea sativa, } \\
\text { Picea abies }\end{array}$ & $\begin{array}{l}\text { Humic } \\
\text { Umbrisol }^{2)} \\
\text { Cryptopodzol }^{1)}\end{array}$ & $\begin{array}{l}\text { Granite, } \\
\text { orthogneiss }\end{array}$ \\
\hline $\begin{array}{l}\text { Sagno/ } \\
\text { Brughee } \\
\text { P4 }\end{array}$ & 730 & SW & 40 & $\begin{array}{l}\text { Castanea sativa, } \\
\text { Fraxinus } \\
\text { excelsior, } \\
\text { Fagus silvatica }\end{array}$ & $\begin{array}{l}\text { Dystric } \\
\text { Cambisol }^{2)}\end{array}$ & $\begin{array}{l}\text { Mesozoic } \\
\text { sediments } \\
\text { (Flysch) }\end{array}$ \\
\hline
\end{tabular}

${ }^{1)}$ Cryptopodzol according to Blaser et al. (1997); ${ }^{2)}$ IUSS Working Group (2006). 
Table 2 Physical properties, $\mathrm{pH}$ and colour $\left(\mathrm{L}^{*}\right)$ of the investigated soils.

\begin{tabular}{|c|c|c|c|c|c|c|c|c|}
\hline \multirow[t]{2}{*}{ Site/horizon } & Depth & $\begin{array}{l}\text { Bulk } \\
\text { density }\end{array}$ & Sand & Silt & Clay & Skeleton & $\mathrm{pH}$ & Colou \\
\hline & $\mathrm{cm}$ & $\mathrm{g} \mathrm{cm}^{-3}$ & $g \mathrm{~kg}^{-1}$ & $g k^{-1}$ & $g \mathrm{~kg}^{-1}$ & $g k^{-1}$ & $\mathrm{CaCl}_{2}$ & $L^{*}$ \\
\hline \multicolumn{9}{|c|}{ Cryptopodzol P1 } \\
\hline A & $0-15$ & 0.39 & 643 & 303 & 54 & 123 & 3.8 & 40.3 \\
\hline$A B$ & $15-50$ & 0.82 & 677 & 270 & 53 & 311 & 4.3 & 45.1 \\
\hline $\mathrm{A} 1 \mathrm{~b}$ & $50-95$ & 1.01 & 563 & 342 & 95 & 214 & 4.3 & 35.0 \\
\hline $\mathrm{A} 2 \mathrm{~b}$ & $95-110$ & 0.74 & 560 & 370 & 70 & 221 & 4.3 & 39.3 \\
\hline Bhsb & $110-140$ & 0.83 & 570 & 380 & 50 & 219 & 4.5 & 41.4 \\
\hline $\mathrm{Bb}$ & $140-200$ & 0.90 & 537 & 407 & 56 & 293 & 4.9 & 52.4 \\
\hline $\mathrm{BCb}$ & $200-220$ & 1.02 & 700 & 270 & 30 & 560 & 4.8 & 57.1 \\
\hline \multicolumn{9}{|c|}{ Cryptopodzol P2 } \\
\hline A & $0-13$ & 0.51 & n.d. & n.d. & n.d. & 19 & 3.5 & 27.5 \\
\hline $\mathrm{AE}$ & $13-30$ & 0.55 & 703 & 220 & 77 & 38 & 4.4 & 25.6 \\
\hline Bhs1 & $30-40$ & 0.61 & n.d. & n.d. & n.d. & 57 & n.d. & 30.4 \\
\hline Bhs2 & $40-50$ & 0.63 & 753 & 184 & 63 & 69 & 4.6 & 34.4 \\
\hline B & $50-68$ & 0.71 & 739 & 177 & 84 & 206 & 5.0 & 43.4 \\
\hline C & $>68$ & & 720 & 222 & 58 & n.d. & 5.1 & 59.6 \\
\hline \multicolumn{9}{|c|}{ Cryptopodzol P3 } \\
\hline A & $0-25$ & 0.45 & 720 & 230 & 45 & 244 & 4.2 & 33.7 \\
\hline$A B$ & $25-35$ & 0.51 & 680 & 270 & 50 & 130 & 4.3 & 33.6 \\
\hline $\mathrm{Bh}$ & $35-55$ & 0.62 & 670 & 300 & 40 & 107 & 4.5 & 34.1 \\
\hline Bhs & $55-85$ & 0.70 & 650 & 330 & 30 & 216 & 4.6 & 41.2 \\
\hline$B C$ & $85-110$ & 0.59 & 810 & 170 & 10 & 220 & 4.7 & 42.1 \\
\hline C & $>110$ & 0.72 & 880 & 110 & 10 & 489 & 4.9 & 54.9 \\
\hline \multicolumn{9}{|l|}{ Cambisol P4 } \\
\hline A & $0-10$ & 0.65 & n.d. & n.d. & n.d. & 102 & n.d. & 47.3 \\
\hline BA & $10-21$ & 0.80 & 370 & 580 & 50 & 89 & 3.2 & 50.3 \\
\hline Bw & $21-40$ & 0.73 & 370 & 579 & 51 & 140 & 4.2 & 49.1 \\
\hline $\mathrm{BC} 1$ & $40-60$ & 0.73 & 457 & 497 & 46 & 141 & 4.4 & 55.5 \\
\hline $\mathrm{BC} 2$ & $60-90$ & 0.59 & n.d. & n.d. & n.d. & 445 & n.d. & 64.8 \\
\hline C & $90-150$ & 0.90 & 697 & 290 & 13 & 528 & 4.4 & 69.8 \\
\hline
\end{tabular}


Table 3 Carbon, nitrogen, BPCA-C and charcoal concentrations and stocks. The sum is given for the stocks in the whole profiles.

\begin{tabular}{|c|c|c|c|c|c|c|c|c|}
\hline $\begin{array}{l}\text { Site/ } \\
\text { horizon }\end{array}$ & $\begin{array}{l}\mathrm{N} \\
g \mathrm{~kg}^{-1}\end{array}$ & $\begin{array}{l}\text { SOC } \\
g_{k g^{-1}}\end{array}$ & $\mathrm{C} / \mathrm{N}$ & $\begin{array}{l}\text { BPCA-C } \\
g k^{-1}\end{array}$ & $\begin{array}{l}\text { BPCA-C/ } \\
\text { SOC } \\
\%\end{array}$ & $\begin{array}{l}\text { SOC } \\
\text { stock } \\
\text { tha }{ }^{-1}\end{array}$ & $\begin{array}{l}\text { Charcoal } \\
\text { stock } \\
\text { tha }{ }^{-1}\end{array}$ & $\begin{array}{l}\text { BPCA-C } \\
\text { stock } \\
t h^{-1}\end{array}$ \\
\hline \multicolumn{9}{|c|}{ Cryptopodzol P1 } \\
\hline$A$ & 3.9 & 73.1 & 19 & 1.1 & 1.5 & 37.2 & 0.1 & 0.5 \\
\hline$A B$ & 0.5 & 19.6 & 38 & 0.8 & 4.1 & 38.7 & 2.1 & 1.6 \\
\hline A1b & 1.6 & 45.2 & 29 & 1.7 & 3.8 & 161.4 & 19.1 & 6.1 \\
\hline$A 2 b$ & 1.0 & 30.5 & 30 & 3.8 & 12.4 & 26.4 & 1.7 & 3.3 \\
\hline Bhsb & 0.8 & 23.8 & 31 & 3.0 & 12.5 & 46.0 & 1.1 & 5.7 \\
\hline $\mathrm{Bb}$ & 0.3 & 6.7 & 22 & 0.0 & 0.0 & 25.6 & 7.1 & 0.0 \\
\hline $\mathrm{BCb}$ & 0.1 & 3.9 & 43 & n.d. & n.d. & 3.5 & 0.0 & n.d. \\
\hline$\Sigma$ & & & & & & 338.8 & 31.2 & 17.2 \\
\hline \multicolumn{9}{|c|}{ Cryptopodzol P2 } \\
\hline A & 6.9 & 119.1 & 17 & 5.7 & 4.8 & 77.7 & 1.3 & 3.7 \\
\hline $\mathrm{AE}$ & 4.5 & 87.5 & 20 & 6.6 & 7.5 & 78.7 & 1.2 & 5.9 \\
\hline Bhs1 & 3.1 & 65.6 & 21 & 6.1 & 9.3 & 38.0 & 1.8 & 3.5 \\
\hline Bhs2 & 2.2 & 44.3 & 20 & 3.4 & 7.7 & 26.1 & 0.1 & 2.0 \\
\hline B & 1.2 & 21.3 & 18 & 0.2 & 0.8 & 20.5 & 0.1 & 0.2 \\
\hline C & 0.2 & 5.8 & 24 & n.d. & n.d. & n.d. & n.d. & n.d. \\
\hline$\Sigma$ & & & & & & 241.0 & 4.5 & 15.3 \\
\hline \multicolumn{9}{|c|}{ Cryptopodzol P3 } \\
\hline A & 5.8 & 93.7 & 16 & 1.2 & 1.2 & 80.1 & 0.2 & 1.0 \\
\hline$A B$ & 3.7 & 62.2 & 17 & 2.7 & 4.3 & 27.4 & 0.1 & 1.2 \\
\hline $\mathrm{Bh}$ & 3.2 & 58.0 & 18 & 1.2 & 2.1 & 63.7 & 0.6 & 1.4 \\
\hline Bhs & 1.4 & 29.9 & 21 & 0.8 & 2.7 & 48.9 & 0.7 & 1.3 \\
\hline $\mathrm{BC}$ & 1.4 & 26.0 & 19 & 1.2 & 4.7 & 29.9 & 0.6 & 1.4 \\
\hline C & 0.0 & 6.4 & n.d. & n.d. & n.d. & n.d. & n.d. & n.d. \\
\hline$\Sigma$ & & & & & & 250.0 & 2.2 & 6.3 \\
\hline \multicolumn{9}{|c|}{ Cambisol P4 } \\
\hline A & 4.2 & 75.4 & 18 & 1.1 & 1.4 & 22.1 & 0.0 & 0.3 \\
\hline BA & 1.6 & 27.0 & 17 & 0.6 & 2.2 & 21.7 & 0.0 & 0.5 \\
\hline Bw & 1.6 & 26.9 & 17 & 0.3 & 1.2 & 32.2 & 0.1 & 0.4 \\
\hline BC1 & 0.7 & 15.5 & 23 & 0.3 & 2.1 & 19.5 & 0.0 & 0.4 \\
\hline $\mathrm{BC} 2$ & 0.6 & 7.5 & 14 & n.d. & n.d. & 7.4 & 0.0 & n.d. \\
\hline C & 0.3 & 2.9 & 10 & n.d. & n.d. & 7.4 & 0.0 & n.d. \\
\hline$\Sigma$ & & & & & & 110.3 & 0.1 & 1.6 \\
\hline
\end{tabular}


Table 4 Concentrations of dithionite (d), oxalate (o) and pyrophosphate (p) extractable $\mathrm{Al}$ and Fe.

\begin{tabular}{|c|c|c|c|c|c|c|}
\hline $\begin{array}{l}\text { Site/ } \\
\text { horizon }\end{array}$ & $\begin{array}{l}\mathrm{Al}_{\mathrm{d}} \\
g \mathrm{~kg}^{-1}\end{array}$ & $\begin{array}{l}\mathrm{Al}_{\circ} \\
g \mathrm{~kg}^{-1}\end{array}$ & $\begin{array}{l}\mathrm{Al}_{\mathrm{p}} \\
g \mathrm{~kg}^{-1}\end{array}$ & $\begin{array}{l}\mathrm{Fe}_{\mathrm{d}} \\
\mathrm{g} \mathrm{kg}^{-1}\end{array}$ & $\begin{array}{l}\mathrm{Fe}_{\circ} \\
\mathrm{g} \mathrm{kg}^{-1}\end{array}$ & $\begin{array}{l}\mathrm{Fe}_{\mathrm{p}} \\
\mathrm{g} \mathrm{kg}^{-1}\end{array}$ \\
\hline \multicolumn{7}{|c|}{ Cryptopodzol P1 } \\
\hline A & 6.5 & 6.0 & 6.0 & 9.0 & 4.6 & 4.6 \\
\hline$A B$ & 6.3 & 9.5 & 5.2 & 10.0 & 6.2 & 2.6 \\
\hline$A 1 b$ & 11.0 & 10.6 & 5.9 & 13.8 & 8.9 & 4.7 \\
\hline $\mathrm{A} 2 \mathrm{~b}$ & 10.4 & 10.9 & 7.7 & 13.8 & 9.4 & 3.9 \\
\hline Bhsb & 9.2 & 11.1 & 5.4 & 14.3 & 9.6 & 2.1 \\
\hline $\mathrm{Bb}$ & 5.6 & 9.0 & 1.7 & 10.4 & 4.9 & 0.3 \\
\hline $\mathrm{BCb}$ & 3.4 & 3.8 & 1.2 & 6.7 & 2.6 & 0.2 \\
\hline \multicolumn{7}{|c|}{ Cryptopodzol P2 } \\
\hline A & 6.4 & 6.2 & 8.7 & 11.6 & 7.9 & 12.1 \\
\hline AE & 14.6 & 10.4 & 14.1 & 12.3 & 5.8 & 9.5 \\
\hline Bhs1 & n.d. & n.d. & n.d. & n.d. & n.d. & n.d. \\
\hline Bhs2 & 13.2 & 11.7 & 10.2 & 12.6 & 4.5 & 6.0 \\
\hline B & 9.0 & 11.4 & 5.2 & 10.8 & 3.6 & 1.9 \\
\hline C & 3.8 & 5.4 & 2.0 & 5.4 & 1.2 & 0.4 \\
\hline \multicolumn{7}{|c|}{ Cryptopodzol P3 } \\
\hline$A$ & n.d. & 8.5 & 6.2 & 11.9 & 7.0 & 4.2 \\
\hline$A B$ & n.d. & 9.4 & 6.6 & 13.4 & 7.9 & 4.8 \\
\hline $\mathrm{Bh}$ & n.d. & 9.8 & 4.9 & 13.0 & 7.6 & 3.3 \\
\hline Bhs & n.d. & 8.1 & 3.5 & 12.5 & 6.8 & 2.0 \\
\hline $\mathrm{BC}$ & n.d. & 3.9 & 1.3 & 9.3 & 4.0 & 0.4 \\
\hline C & n.d. & 4.0 & 0.9 & 5.9 & 2.1 & 0.2 \\
\hline \multicolumn{7}{|c|}{ Cambisol P4 } \\
\hline$A$ & n.d. & n.d. & n.d. & n.d. & n.d. & n.d. \\
\hline BA & 2.4 & 1.5 & 2.2 & 5.8 & 2.8 & 4.2 \\
\hline Bw & 3.2 & 2.1 & 3.4 & 6.1 & 3.5 & 5.8 \\
\hline $\mathrm{BC} 1$ & 3.9 & 2.5 & 3.1 & 5.7 & 2.8 & 3.8 \\
\hline $\mathrm{BC} 2$ & n.d. & n.d. & n.d. & n.d. & n.d. & n.d. \\
\hline $\mathrm{C}$ & 4.3 & 3.1 & 3.8 & 5.8 & 2.4 & 3.6 \\
\hline
\end{tabular}

n.d. $=$ not determined 
Table 5 Carbon and nitrogen concentrations in the density fractions.

\begin{tabular}{|c|c|c|c|c|c|c|c|c|c|c|c|c|}
\hline \multirow{2}{*}{$\begin{array}{l}\text { Site/ } \\
\text { horizon }\end{array}$} & \multicolumn{2}{|c|}{$<1 \mathrm{~g} \mathrm{~kg}^{-1}$} & \multicolumn{4}{|c|}{$1-2 \mathrm{~g} \mathrm{~kg}^{-1}$} & \multicolumn{3}{|c|}{$2-2.4 \mathrm{~g} \mathrm{~kg}^{-1}$} & \multicolumn{3}{|c|}{$>2.4 \mathrm{~g} \mathrm{~kg}^{-1}$} \\
\hline & $\begin{array}{l}\text { Corg } \\
g k^{-1}\end{array}$ & $\mathrm{~N}$ & C:N & $\begin{array}{l}\text { Corg } \\
g k^{-1}\end{array}$ & $\mathrm{~N}$ & $C: N$ & $\begin{array}{l}\text { Corg } \\
g k^{-1}\end{array}$ & $\mathrm{~N}$ & $\mathrm{C}: \mathrm{N}$ & $\begin{array}{l}\text { Corg } \\
g \mathrm{~kg}^{-1}\end{array}$ & $\mathrm{~N}$ & $\mathrm{C}: \mathrm{N}$ \\
\hline \multicolumn{13}{|c|}{ Cryptopodzol P1 } \\
\hline A & 392.3 & 13.7 & 29 & 213.6 & 11.2 & 19 & 86.1 & 4.8 & 18 & 5.8 & 0.2 & 36 \\
\hline$A B$ & 357.3 & 7.7 & 47 & 285.2 & 7.0 & 41 & 67.9 & 2.9 & 24 & 2.9 & 0.0 & \\
\hline $\mathrm{A} 1 \mathrm{~b}$ & 360.3 & 8.3 & 43 & 295.8 & 8.3 & 36 & 85.9 & 3.5 & 24 & 5.9 & 0.1 & 45 \\
\hline $\mathrm{A} 2 \mathrm{~b}$ & 357.1 & 7.2 & 50 & 234.9 & 6.5 & 36 & 68.6 & 3.4 & 20 & 4.6 & 0.2 & 24 \\
\hline Bhsb & 316.9 & 7.3 & 44 & 301.1 & 7.2 & 42 & 24.6 & 1.2 & 21 & 3.5 & 0.2 & 20 \\
\hline $\mathrm{Bb}$ & n.d. & n.d. & n.d. & 300.8 & 7.3 & 41 & 34.7 & 2.0 & 18 & 3.1 & 0.1 & 25 \\
\hline $\mathrm{BCb}$ & n.d. & n.d. & n.d. & 37.5 & 1.2 & 32 & 30.3 & 1.4 & 22 & 2.1 & 0.1 & 19 \\
\hline \multicolumn{13}{|c|}{ Cryptopodzol P2 } \\
\hline A & 184.5 & 10.4 & 18 & 213.7 & 12.2 & 18 & 70.0 & 4.6 & 15 & 1.6 & 0.3 & 5 \\
\hline $\mathrm{AE}$ & 227.7 & 8.7 & 26 & 218.9 & 10.7 & 20 & 71.1 & 4.1 & 17 & 6.2 & 0.0 & \\
\hline Bhs1 & n.d. & n.d. & n.d. & 217.2 & 10.8 & 20 & 80.3 & 5.1 & 16 & 6.7 & 0.2 & 28 \\
\hline Bhs2 & 298.1 & 8.6 & 35 & 201.9 & 8.8 & 23 & 59.8 & 3.7 & 16 & 6.2 & 0.9 & 7 \\
\hline B & 273.1 & 8.5 & 32 & 188.6 & 7.7 & 24 & 48.6 & 3.5 & 14 & 5.1 & 0.3 & 16 \\
\hline C & n.d. & n.d. & n.d. & 122.0 & 9.0 & 14 & 25.0 & 2.6 & 10 & 2.1 & 0.1 & 15 \\
\hline \multicolumn{13}{|c|}{ Cryptopodzol P3 } \\
\hline A & 343.0 & 13.9 & 25 & 204.8 & 13.2 & 15 & 75.0 & 4.6 & 16 & 7.1 & 0.2 & 47 \\
\hline$A B$ & 279.3 & 11.2 & 25 & 219.5 & 10.9 & 20 & 97.6 & 6.2 & 16 & 7.2 & 0.2 & 34 \\
\hline $\mathrm{Bh}$ & 332.8 & 9.5 & 35 & 216.0 & 9.8 & 22 & 75.2 & 4.8 & 16 & 6.1 & 0.3 & 23 \\
\hline Bhs & 383.8 & 8.1 & 47 & 252.7 & 9.4 & 27 & 32.4 & 2.3 & 14 & 6.6 & 0.3 & 26 \\
\hline $\mathrm{BC}$ & 212.5 & 9.0 & 24 & 243.0 & 7.5 & 32 & 45.5 & 3.0 & 15 & 5.4 & 0.2 & 26 \\
\hline C & 228.0 & 5.9 & 39 & n.d. & n.d. & n.d. & 36.4 & 1.3 & 27 & 2.0 & 0.1 & 22 \\
\hline \multicolumn{13}{|c|}{ Cambisol P4 } \\
\hline A & 228.0 & 11.3 & 20 & 227.6 & 12.1 & 19 & 99.1 & 7.1 & 14 & 5.2 & 0.6 & 10 \\
\hline BA & 231.5 & 7.6 & 30 & 247.0 & 9.4 & 26 & 35.7 & 2.8 & 13 & 4.6 & 0.0 & \\
\hline Bw & 274.2 & 9.6 & 28 & 243.0 & 9.9 & 24 & 43.9 & 3.6 & 12 & 4.4 & 0.2 & 28 \\
\hline $\mathrm{BC} 1$ & 274.9 & 7.9 & 35 & 275.5 & 7.6 & 36 & 35.8 & 2.9 & 13 & 4.6 & 0.3 & 16 \\
\hline $\mathrm{BC} 2$ & 346.3 & 8.9 & 39 & n.d. & n.d. & n.d. & 25.9 & 2.3 & 11 & 3.5 & 0.7 & 5 \\
\hline C & 252.7 & 9.2 & 27 & n.d. & n.d. & n.d. & 7.3 & 1.9 & 4 & 1.6 & 0.1 & 15 \\
\hline
\end{tabular}




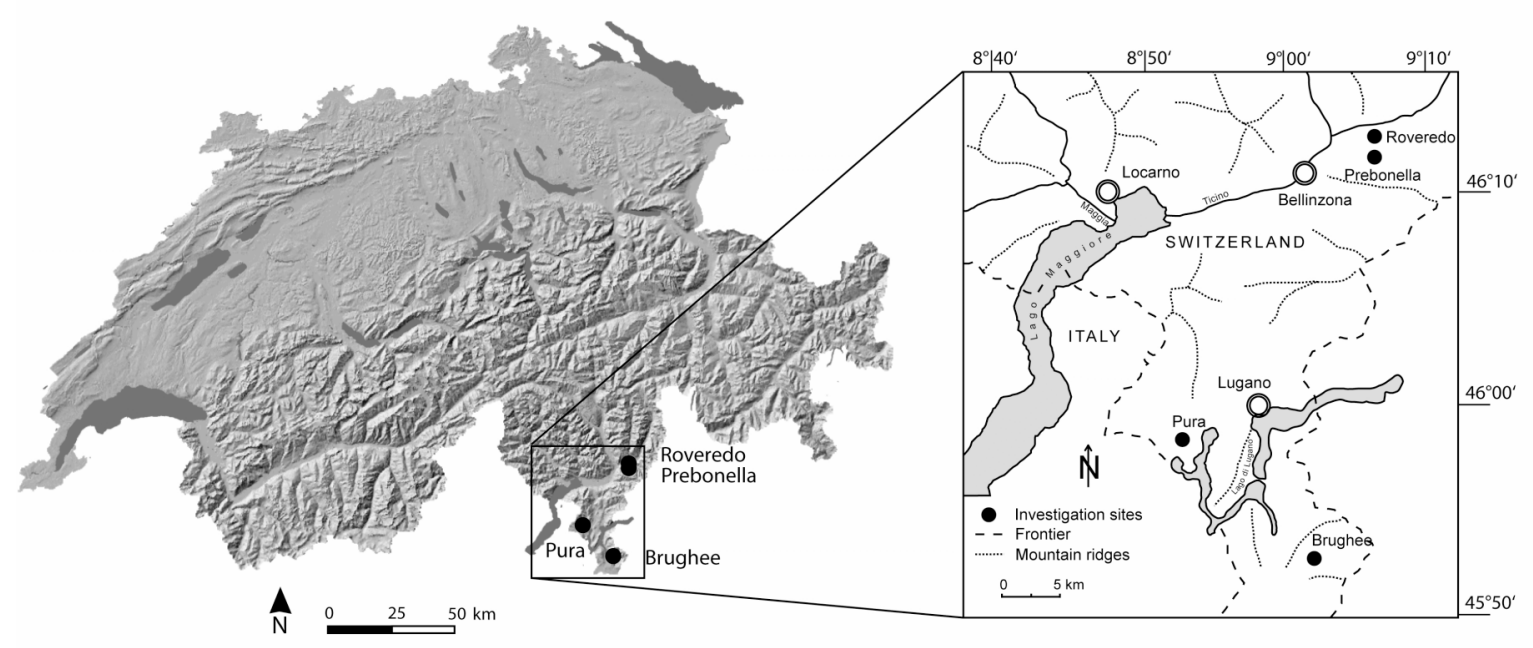

Figure 1 Map of Switzerland showing the investigation area in southern Switzerland and the location of the soil profiles (black dots): Cryptopodzol Roveredo (P1), Cryptopodzol Pura (P2), Cryptopodzol Prebonella (P3) and Cambisol Sagno/Brughee (P4). 


\section{SOC in density fractions}
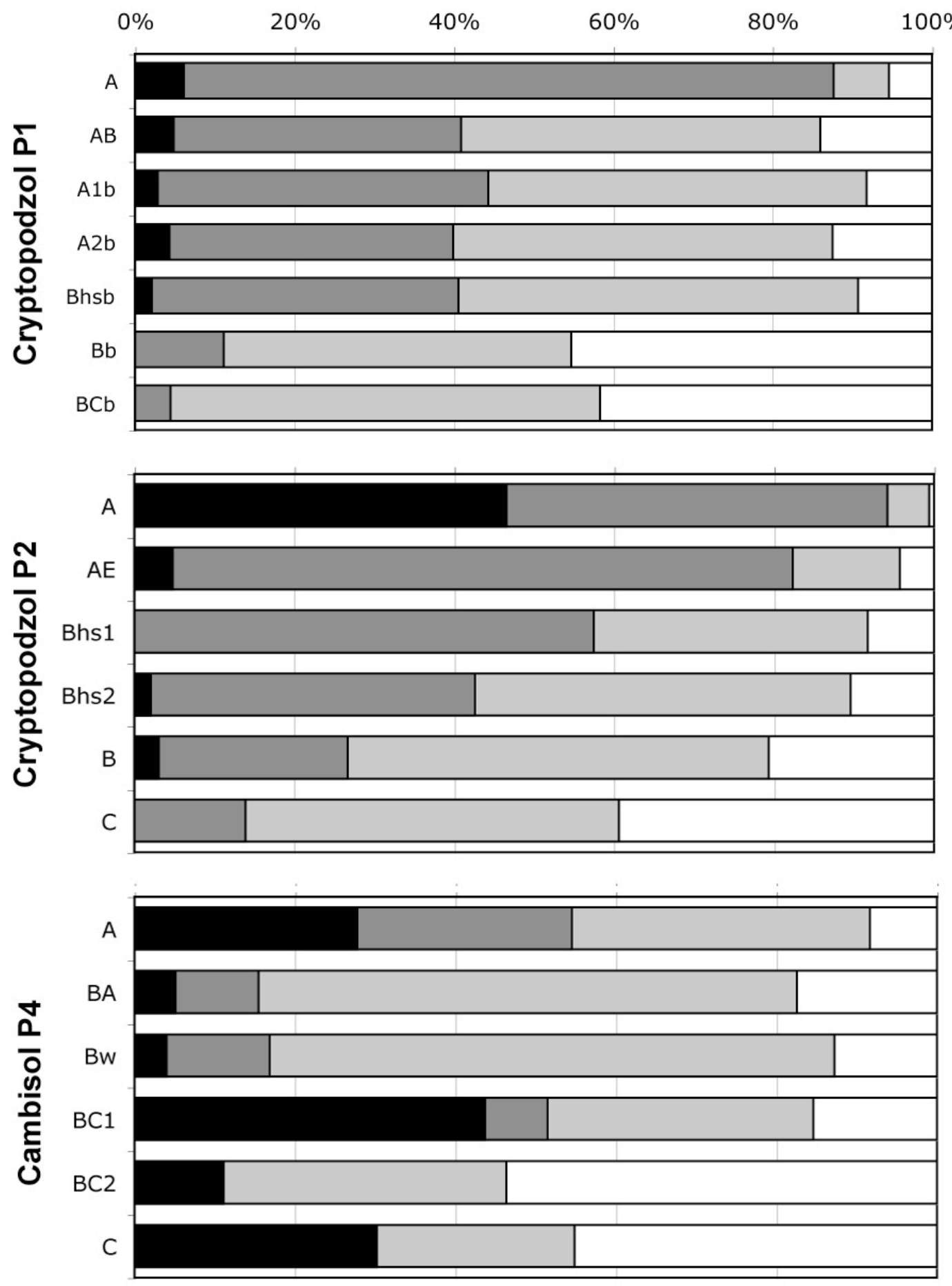

$<1 \mathrm{~g} \mathrm{~cm}^{-3} \square 1-2 \mathrm{~g} \mathrm{~cm}^{-3} \square 2-2.4 \mathrm{~g} \mathrm{~cm}^{-3} \square>2.4 \mathrm{~g} \mathrm{~cm}^{-3}$

Figure 2 The proportion of SOC in the lightest (black), light (dark grey), intermediate (grey) and heavy (white) density fractions, shown for Cryptopodzols P1 and P2 and Cambisol P4. 

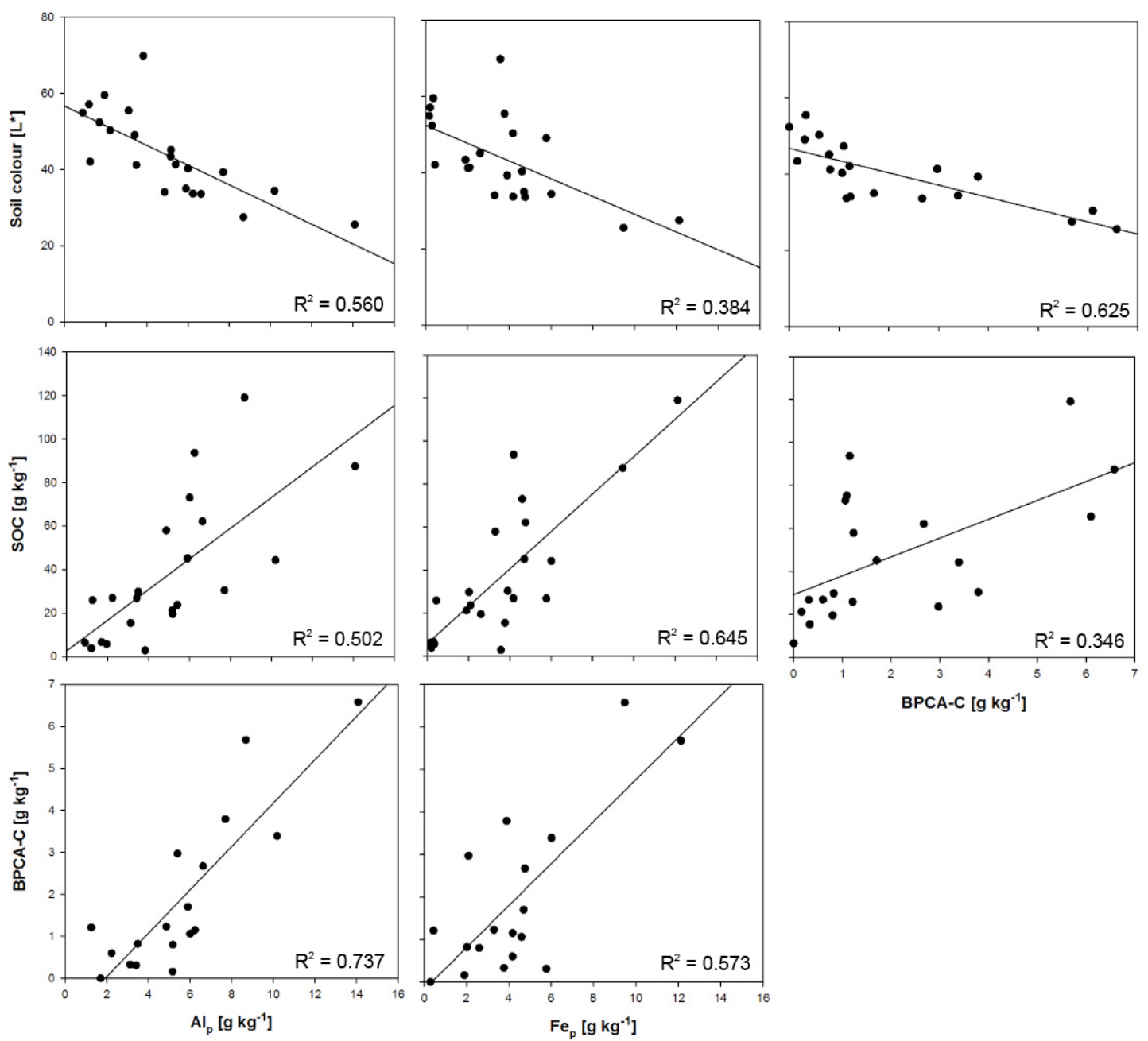

Figure 3 Relationships between soil colour $\left(\mathrm{L}^{*}\right)$, soil organic carbon (SOC), BPCA carbon (BPCA-C), and pyrophosphate extractable $\mathrm{Fe}\left(\mathrm{Fe}_{\mathrm{p}}\right)$ and $\mathrm{Al}\left(\mathrm{Al}_{\mathrm{p}}\right)$. 

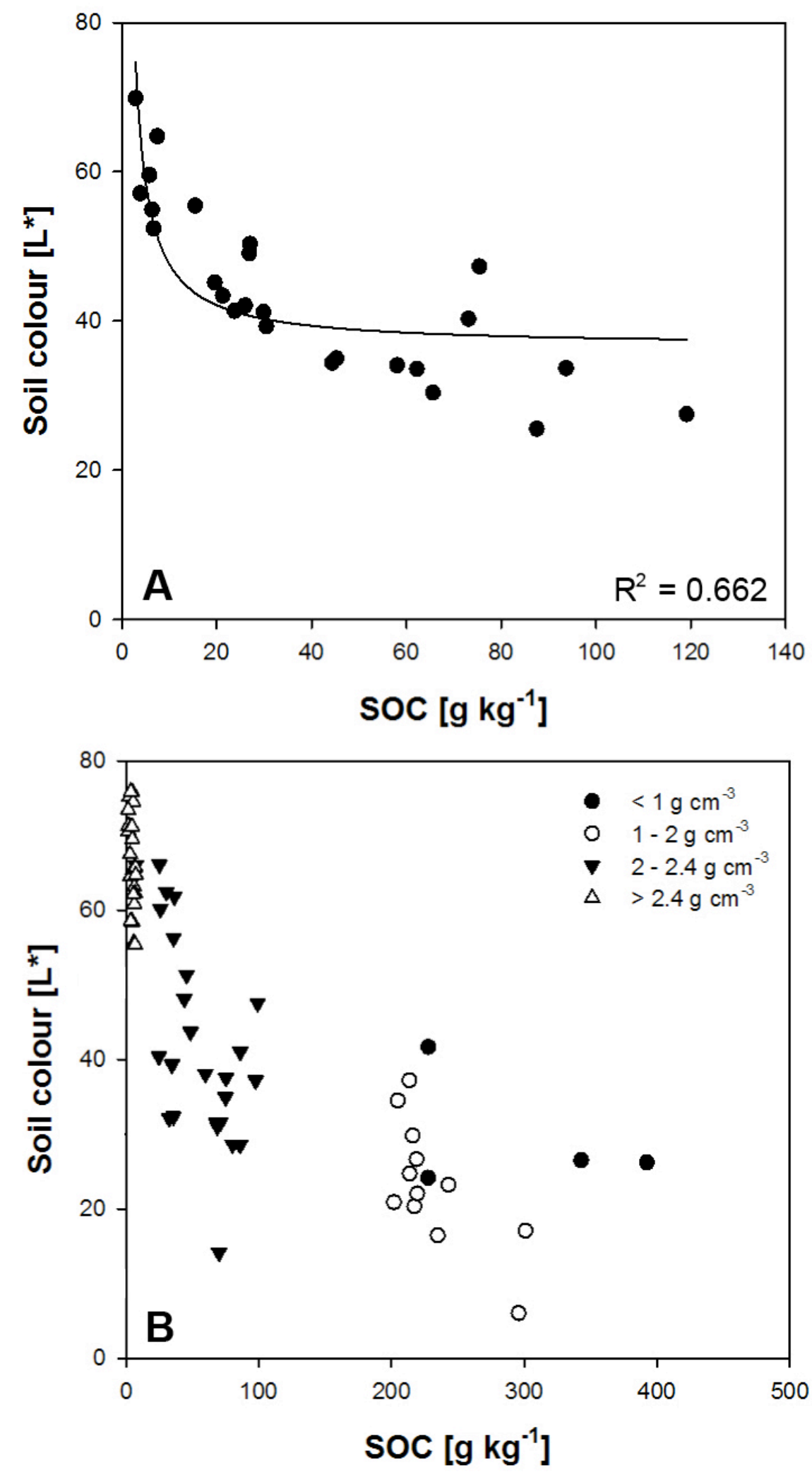

Figure 4 Relationships between soil colour $\left(\mathrm{L}^{*}\right)$ and soil organic carbon (SOC) in all bulk soil samples (A), and in the density fractions (B). 